\title{
The Influence of Avian Biodiversity and a Weedy Understorey on Canopy Arthropod Assembly
}

\author{
Kathryn Teare Ada Lambert, Nigel R. Andrew, Paul G. McDonald \\ Centre for Behavioural and Physiological Ecology, Zoology, University of New England, Armidale, Australia \\ Email: kathryn.ta.lambert@gmail.com
}

Received 3 November 2014; revised 2 December 2014; accepted 9 December 2014

Academic Editor: Victor R. Savage, National University of Singapore, Singapore

Copyright (C) 2014 by authors and Scientific Research Publishing Inc.

This work is licensed under the Creative Commons Attribution International License (CC BY). http://creativecommons.org/licenses/by/4.0/

(c) (i) Open Access

\begin{abstract}
Identifying the factor causing species decline from a multitude of potential disturbances is essential for successful management. Invasive species are often drivers of decline, either through direct effects such as recruitment limitation, or through indirect effects such as habitat modification that facilitate biota changes in other taxa. In this study, we tested the importance of bird predation on arthropods in eucalypt canopies in wet sclerophyll forest that had been invaded by the understorey weed Lantana camara. A strong top-down effect is in agreement with studies that show elevated numbers of insectivorous birds, such as the despotic bell miner, Manorina melanophrys, reduce damaging herbivorous insect numbers and their effect on tree health. Abundance, order and family composition were compared among sites, feeding guilds, among the presence and absence of a despotic bird, and among presence and absence within sites, using a three-way nested Multivariate Analysis of Variance (MANOVA), and tested our representation of insect feeding guilds with rarefaction curves. In total, we found arthropods from 20 families on eucalypt trees, 16 where bell miners were present and 18 where they were absent (a sampling efficiency of $78 \%$ and $92 \%$ of families based on the Chao-I index). Overall, there was a difference in the abundance of insects in areas where bell miners were present $(n=181)$, and where they were absent $(n=67)$. There was also a difference in the families present in areas with bell miners and without them. Under some conditions, despotic birds may not change the insect canopy community. Further studies should examine the effects of a despotic bird on the insect canopy community in a variety of conditions and throughout their range.
\end{abstract}

\section{Keywords}

Despotic Birds, Disturbance, Insects, Canopy, Tritrophic Relationships 


\section{Introduction}

Anthropogenic disturbance has led to the degradation of forests on a global scale. The spread of invasive species, logging, grazing and fire threaten a variety of forest types [1]. Despite a range of studies examining individual disturbance effects in isolation, how a combination of disturbance factors influence forest condition has rarely been examined [2]. The examination of multiple disturbances to detect what is responsible for species decline is essential for invasive species management, however this is often difficult to identify. Direct effects, such as recruitment limitation, can be caused by invasive species [3], and indirectly through providing habitat for despotic species, particularly generalist species [4]. Reasons for greater use of disturbed habitats by birds remain speculative (intermediate disturbance hypothesis), but abundant food and protection from predators have been proposed as likely drivers [5] [6]. Arthropod populations are also influenced by disturbance [7]. Sites with the greatest resource availability and invertebrate biomass are advantageous for birds in terms of daily nest survival rates, nestling growth rates [8], and predation avoidance. Experimental prey removal has not linked negative consequences for the bird community with decreased prey abundance [9]. High bird abundance has, instead, been linked with complex understorey and midstorey vegetation structure [10].

In this study, we tested the differences in arthropod assemblages in habitats with and without highly despotic bell miners, Manorina melanophrys, with a weedy understorey of Lantana camara in eucalypt canopies in wet sclerophyll forest. Bell miners are despotic, excluding all other avian taxa from an area [11], to possibly defend a food source and remove all other insectivorous predators [12]. Additionally, it has been suggested that this species uses thick or weedy understories for nesting [13]. If bird presence is related to arthropod abundance, then areas with a higher avian species richness, particularly insectivorous birds, will initially have a higher abundance of insects, greater family and feeding guild diversity that will eventually be reduced by continuous foraging e.g. [14]-[16]. Consequently, the invasion of an exotic weed that provides suitable habitat for an aggressive and despotic avian species may indirectly have an impact on birds. The importance of indirect management effects to the breeding success of insectivorous birds has recently been stressed as an important conservation consideration [17]. Quantifying the impact of disturbance from invasive species in forests should be performed on a regular basis to help prevent changes in biodiversity such as creating suboptimal habitats for birds.

The top-down effects of birds on arthropods have been examined in numerous forest ecosystems [4] [18] [19], and indirectly for both deciduous and coniferous trees [18] [20]. The abundance of arthropods and their community assemblage can be significantly impacted by predation by insectivorous birds [21], and, furthermore, this predation is an evolutionary force shaping a variety of arthropod characteristics including sex ratio, colouration and behaviour [19]. A strong top-down effect is in agreement with studies that show high numbers of insectivorous birds reduce damaging herbivorous insect numbers and their effect on tree health e.g. [22]-[25], or a reduction of insectivorous birds and the increase of a despotic species results in an indirect increase in damaging herbivorous insects e.g. [14] [26]-[28].

Most woodland birds are territorial for at least part of the year. Wilson [29] defines a territory as an area occupied entirely by an animal or group of animals by repulsion through explicit defence or announcement. These areas can have definite borders where distinctive behaviours are displayed e.g. [30] [31] or where core areas are defended with overlapping home ranges e.g. [32]. Despoticity is usually species specific where groups of animals from a particular species exclude other groups from the same species e.g. [33]-[35]. However, some species exclude others interspecifically to monopolise resources. Nectarivorous bird species such as honeyeaters of the family Meliphagidae, for example, aggressively dominate areas with high levels of flowering or nectar production. Larger species can use interference competition to dominate resources from smaller insectivorous species that may have to locate areas with poorer resources [36]. Hummingbird assemblages provide a similar example [37]. The presence of an aggressively dominantbird species creates exclusion zones that may have reduced avian diversity e.g. [22] [38], and thus allow high insect populations e.g. [14] [15].

Evidence suggests that bell miner colonies defend areas containing high levels of damaging insect populations, particularly psyllids, from other insectivorous birds, indirectly leading to the death of canopy trees [12] [14] [39] [40]. Chewing insects have been found to be the most damaging insects in eucalypts [41], and one of feeding guilds that bell miner chicks and adults consume [42] [43]. However, psyllid nymphs, that produce a sugaryprotective coating and feed on the sap of leaves, have been implicated in increased levels of damage in trees, particularly in association with bell miners [12] [44]. This relationship is an extreme example of creating exclusion zones as it has been associated with tree death, known as bell miner associated dieback [11] [45]. Yet, little 
is known about the top-down effects of bell miners on the insect populations in their territories.

To predict the impact of organisms on ecosystems, functional diversity can be used, as it can show a link between organisms and ecosystems. Functional diversity commonly involves examining communities and ecosystems, based on the role of an organism or its trophic level, regardless of their evolutionary history. Determining which traits to include in a measure of functional diversity depends on the aims of the study [46]. In terms of our study, we wanted to know whether bell miners influenced the trophic levels of canopy insects, to test whether this influence was causing an increase in herbivory and leaf damage. As insect families are varied and numerous with significant influence on ecosystem function, we placed each family into a feeding guild as specified by [47]. A hierarchy of functional diversity groups can be used to examine how changes in biotic diversity might affect ecosystem properties, in the short term and in response to the influences of environmental conditions. Examining these groups can lead to a better understanding of how community assembly influences relationships between organisms and functional diversity in communities and how this might vary in different environments [48] [49].

Our specific hypotheses were: (1) arthropod abundance will be higher in areas with an avian despotic species, where all other avian insectivorous species are excluded because the removal of avian predators has been shown to increase insect numbers and, (2) the number of feeding guilds will be higher in areas with a lower avian species richness as a reduction in avian predators allows insect feeding guilds to increase in number, particularly the with a reduction in the number of predatory insects.

\section{Methods}

\subsection{Study Species}

For this study, we chose the despotic bell miner that is endemic to eastern Australia, ranging from Gympie, Queensland to Melbourne, Victoria [13]. This cooperatively breeding species feeds as part of a colony, consuming primarily insects from the foliage and bark of eucalypts [12] [14] [50] [51]. Colonies inhabit open eucalypt forests and woodlands with a thick understorey in broad gullies of foothills, usually at edges of rainforest areas [13].

\subsection{Study Area}

Fieldwork was conducted in December 2013 at Dorrigo National Park (S30 23.361', E152 $\left.{ }^{\circ} 50.394^{\prime}\right)$ and Gibraltar Range National Park (S29 $27^{\prime} 13.9^{\prime \prime}$, E152 $\left.22^{\prime} 32.6^{\prime \prime}\right)$. Each study site had one sampling plot containing bell miners, Manorina melanophrys, and one as a control without bell miners. All plots contained similar vegetation types of wet sclerophyll forest with an understorey of Lantana, Lantana camara. Average annual rainfall is $1520.4 \mathrm{~mm}$ and $856.5 \mathrm{~mm}$ at Dorrigo National Park and Gilbraltar Range National Park, respectively [52] [53]. Each site contained one eucalypt inside the boundary of a bell miner colony and one eucalypt outside the boundary, approximately $100 \mathrm{~m}$ apart. Eucalypts were chosen to show a representation of the insect canopy assemblage of areas containing psyllids and their feeding guilds and the interaction with bell miners. Trees were chosen within bell miner colonies and on the boundary where birds were not observed.

\subsection{Sampling}

To minimise vegetation type variation and bias, the insects inhabiting Eucalyptus canopies were collected using a Stihl SG 40 Blower Sprayer for fogging with cones of one metre diameter placed in four compass directions in the understorey. Areas for fogging were chosen that contained a majority of eucalypts and accessibility of branches for fogging [54]. To minimise the effect of wind, fogging was completed during relatively still $(<1$ $\mathrm{m} \cdot \mathrm{s}^{-1}$ as measured by a Kestrel 2004, Nielsen-Kellerman, USA) mornings (07:30-11:00) and only during dry weather following Andrew \& Hughes [55] [56].

Sample collection involved hoisting the fogger into the canopy using a rope and a filled water bottle attached to fishing wire. Once the rope was securely hoisted into a branch of the selected tree at a minimum of $10 \mathrm{~m}$, the fogger was lifted using a rope-and-pulley system. The tree was fogged using $5 \mathrm{~mL}$ of pyrethrum in $10 \mathrm{~L}$ of water. Cones, with a $500 \mathrm{~mL}$ vial connected to the centre into which insects that fell or were washed into using $70 \%$ ethanol, were placed below the fogger for insect collection in four compass directions. Each sampling area was fogged for five to ten minutes ensuring that the fog penetrated the canopy. After 40 - 50 minutes, the catch was 
removed from the cones in 70\% ethanol. Samples were labelled and kept in ethanol beakers.

We recorded the abundance of every arthropod collected, identified them to family based on the classifications by Zborowski and Storey [47], to ensure accurate assignment to a specific feeding guild. This approach was designed to yield repeatable, informative data from comprehensive samples generated by insecticidal fogging [57]. We used a combination of traits to classify arthropods, incorporating wing presence, developmental stage and feeding mode.

\subsection{Data Analysis}

Abundance and feeding guilds of the arthropod community were compared among sites, in the presence and absence of a despotic bird, and among presence and absence within sites, using a three-way nested Multivariate Analysis of Variance (MANOVA). In addition, each feeding group was compared among sites and presence using the same statistical method. Furthermore, Family presence was compared among sites and, considering presence within sites using a two-way Analysis of Variance (ANOVA; SPSS version 22.0) [49] [58]. Moreover, we used rarefaction curves and the Chao index to determine whether the number of feeding guilds collected is a true representation of the feeding guilds that inhabit the area. The slope of the curve represents normality within the data [59].

\section{Results}

\subsection{Arthropod Abundances}

In total, we found arthropods from 13 Orders on eucalypt trees across the entire study, 12 where bell miners were present and 9 where bell miners were absent. The most abundant Orders at sites occupied by bell miners were Diptera (30\% of total arthropods), Hymenoptera (28\%), Coleoptera (13\%), Pscoptera (10\%) and Araneae (7\%). Conversely, the most abundant Orders at sites where bell miners were absent were Diptera (34\%), Hymenoptera (22\%), Coleoptera (19\%), Araneae (9\%) and Hemiptera (7\%). However, there was no significant difference in the presence of Orders between sites $\left(\mathrm{F}_{19,18}=5.40, \mathrm{p}=0.69\right)$. Odonata was the only Order not present where bell miners were located. Conversely, Pscoptera, Acarina, Thysanoptera and Neuroptera were not present in trees where bell miners were absent. As Odonata and Neuroptera were the only Orders that could be assigned to a specific feeding guild, we then identified families that were present from these Orders and placed them into feeding guilds in areas either occupied or not by Bell Miners at each site.

In total, we found arthropods from 20 families on eucalypt trees, 16 where bell miners were present (Chao index $=78 \%$ ) and 18 where they were absent (Chao index $=92 \%$ ). From this, we determined our sampling effort of arthropod families was 78\% and 92\% respectively. Overall, Although there was no difference when site variance was included $\left(\mathrm{F}_{1,50}=1.43, \mathrm{p}=0.237\right)$, the abundance of insects in areas where bell miners were present and where they were absent was 181 and 67, respectively.

\subsection{Effect of Despotic Bird Presence on Arthropod Community Structure}

The presence of bell miners had no significant effect on the presence of feeding groups, except for the unknown family when sites were included as a variable (Table 1). However, when feeding groups were pooled, bell miner presence showed an increase in insect abundance in each feeding guild and overall (Figure 1). Furthermore, there was no significant difference in the families present in areas with bell miners and without them (Table 1; Table 2).

\section{Discussion}

Our experimental results showed that the presence of a despotic bird and the reduction of avian diversity had no significant effect on arthropod abundance when site variance was included, but an overall difference was observed, in that a higher number of arthropods were recorded in areas with bell miners. Earlier experimental results that sampled insect abundance and assemblage where bell miners were present e.g. [51] [60] [61], as well as data from studies on despotic avian species e.g. [26]-[28], have shown similar effects for canopy arthropods. Our results also showed that the assemblage of the insect canopy community was not significantly affected by bell miner presence. However, the presence of particular predators, herbivores and nectivorous species did vary 
Table 1. Summary table of three-way MANOVA for family for the component feeding groups (predator, chewer, sapsucker, ants, various, decomposer, unknown, nectar and pollen, and total abundance) associated with eucalypts. Significant sources of variation are in bold.

\begin{tabular}{|c|c|c|c|}
\hline Factor & df & $F$ & $\mathrm{p}$ \\
\hline \multicolumn{4}{|l|}{ Presence $\times$ Site } \\
\hline Predator & 2 & 1.51 & 0.31 \\
\hline Chewer & 2 & 2.21 & 0.21 \\
\hline Sapsucker & 2 & 0.95 & 0.45 \\
\hline Ant & 2 & 0.57 & 0.60 \\
\hline Various & 2 & 1.45 & 0.32 \\
\hline Decomposer & 2 & 0.63 & 0.57 \\
\hline Nectar/Pollen & 2 & 3.21 & 0.13 \\
\hline Total Abundance & 2 & 0.61 & 0.58 \\
\hline \multicolumn{4}{|l|}{ Site } \\
\hline Predator & 1 & 2.05 & 0.21 \\
\hline Chewer & 1 & 1.30 & 0.31 \\
\hline Sapsucker & 1 & 2.14 & 0.20 \\
\hline Ant & 1 & 1.25 & 0.32 \\
\hline Various & 1 & 0.16 & 0.71 \\
\hline Decomposer & 1 & 1.00 & 0.36 \\
\hline Unknown & 1 & 3.24 & 0.13 \\
\hline Nectar/Pollen & 1 & 2.14 & 0.20 \\
\hline Total Abundance & 1 & 0.28 & 0.62 \\
\hline \multicolumn{4}{|l|}{ Presence } \\
\hline Predator & 1 & 2.56 & 0.17 \\
\hline Chewer & 1 & 0.94 & 0.38 \\
\hline Sapsucker & 1 & 1.19 & 0.33 \\
\hline Ant & 1 & 0.85 & 0.40 \\
\hline Various & 1 & 1.79 & 0.24 \\
\hline Decomposer & 1 & 0.20 & 0.67 \\
\hline Unknown & 1 & 2.40 & 0.18 \\
\hline Nectar/Pollen & 1 & 1.19 & 0.33 \\
\hline Total Abundance & 1 & 1.81 & 0.24 \\
\hline
\end{tabular}


Table 2. A comparison of the families collected in areas where bell miners were present and where they were absent ( $\checkmark=$ yes). Bold indicates families that were not found in both areas.

\begin{tabular}{ccc}
\hline Family & Presence & Absence \\
\hline Apocrita (Wasps) & $\checkmark$ & $\checkmark$ \\
Formicide & $\checkmark$ & $\checkmark$ \\
Symphyta & $\checkmark$ & $\checkmark$ \\
Apiformes & $\checkmark$ & \\
Lepidoptera (Caterpillar) & $\checkmark$ & $\checkmark$ \\
Lepidoptera (Adult) & $\checkmark$ & $\checkmark$ \\
Miridae & $\checkmark$ & $\checkmark$ \\
Cicadellidae & $\checkmark$ & $\checkmark$ \\
Lygaeidae & & $\checkmark$ \\
Collembola & & $\checkmark$ \\
Psyllidae & $\checkmark$ & $\checkmark$ \\
Curculionidae & & $\checkmark$ \\
Scarabaeidae & & $\checkmark$ \\
Limnichidae & $\checkmark$ & $\checkmark$ \\
Mordellidae & $\checkmark$ & \\
Chrysomelidae & & \\
Unknown (1) & & $\checkmark$ \\
Unknown (2) & & \\
Unknown (3) & & $\checkmark$ \\
Staphylinidae & & $\checkmark$ \\
\hline
\end{tabular}

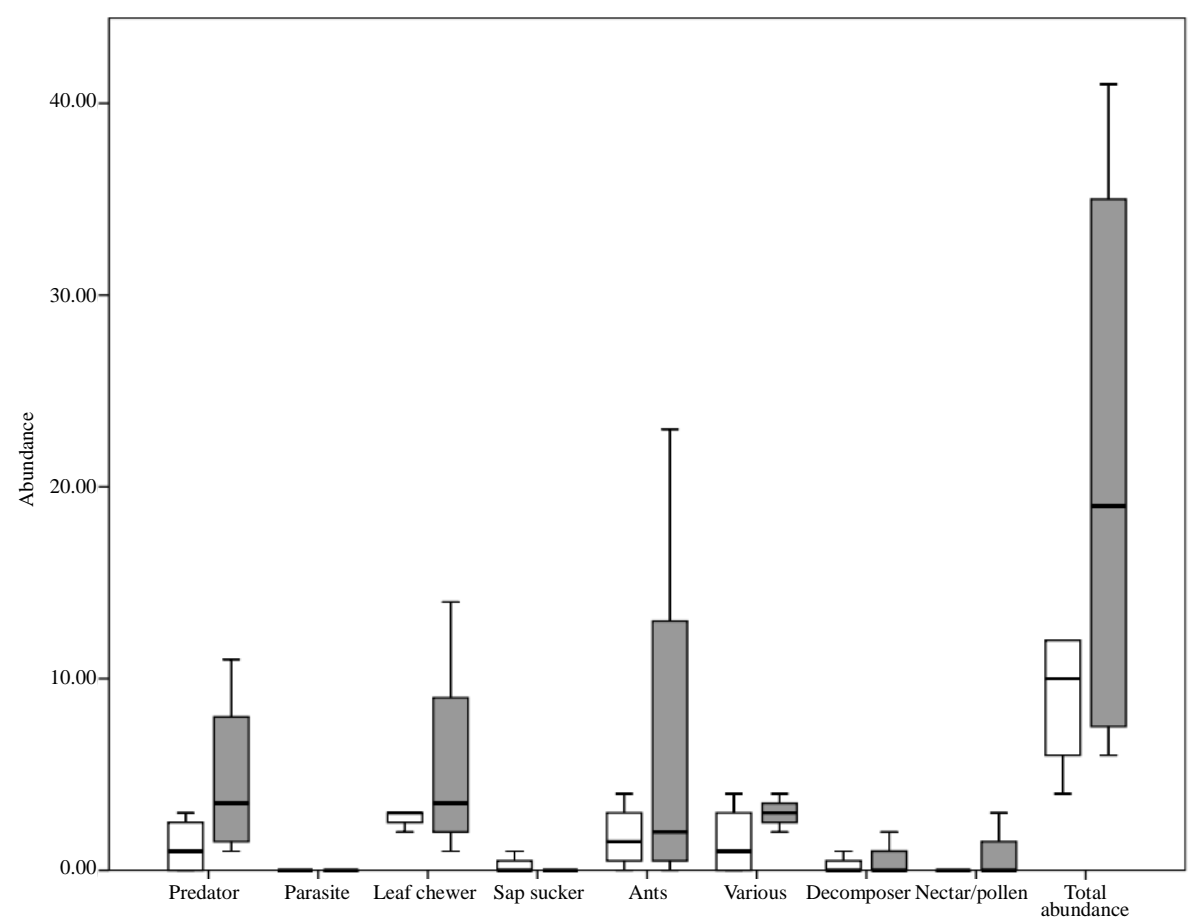

Figure 1. A comparison of insect feeding guilds in sites pooled in areas where bell miners (Manorina melanophrys) were present (grey) and absent (white; $n=7$ ). Lines in boxes represents median. 
among areas where bell miners were either present or absent. Lygaeidae (herbivores) were present where bell miners were found, whereas, Staphylinidae (predators) were present in areas without bell miners. If birds prefer to forage in areas with a high insect abundance, management of disturbance could be adjusted to preserve habitat for a variety of insectivorous birds and reduce despotic bird habitat preferences. The interaction between forest management and bird foraging is important e.g. [12] [26] [62], but little is known about this relationship and it needs further examination [18].

The effects we present differ to those reported by Stone [63], who found that bell miner presence influenced insect abundance by exploitation and, therefore, leaf survival. Bell miner density was found to negatively influence leaf survival as exclusion significantly increased the life expectancy of leaves, nearly double the survival of leaves that were exposed [63]. Additionally, Poiani [60] sampled habitat quality in terms of insect abundance for two miner colonies occupying dry sclerophyll vegetation, finding that general insect abundance in the canopy and midstorey was higher with higher miner density. Furthermore, Poiani [64] examined the stomach contents of bell miners and found that they had consumed a variety of arthropods including specimens from Orders Coleoptera, Hymenoptera, Diptera, Lepidoptera and Aranea as well as psyllids (Hemiptera). Yet, despite a small sample size, a comparison of lerps and arthropod differences between birds found no evidence to suggest that more arthropods were eaten to replace lerp consumption. Dare [65] found that sites with bell miners had higher abundances of lerp than those without. However, psyllids were only recorded where half of the colonies were found. On the other hand, our results contrast the effects observed in other studies where bell miners were found in areas with high numbers of psyllids, causing leaf damage e.g. [22] [63] [66] [67]. We found only one record of a psyllid species, on one of the trees where bell miners were not present but this was potentially an acacia herbivore that may have been travelling through the area when the fogging was completed.

The absence of statistically significant effects in our study is not simply due to a lack of power. A larger sample size would reduce the standard errors, but not alter the treatment means. The species accumulation curve suggests that our small sample size result would be unaffected by increasing the level of replication. Our results, therefore, indicate that bell miners may have an effect on the number of canopy insects present and the insect canopy assemblage but there is variability between sites.

Many studies use abundance as a metric to examine the impact of avian predators on exposed-feeding insects in an exclusion or manipulation experiment where birds are removed or exclusion cages are used e.g. [14] [22] [63]. However, we used the presence and absence of feeding bell miners to estimate the impact of avian predators. We maintain that, although we used an alternative impact measure, we do not think that our results differ from those previously reported. Many of the studies that examine the impact of avian predators using insect abundance also report results using the presence of colonies and the presence of insects e.g. [43] [64] [65]. In studies reporting data concerning both abundance and presence, the effects identified are similar in all cases [60] [64] [65]. A recent review of the ecosystem services provided by birds concluded that a variety of insectivorous species are required to control insect outbreaks [68]. In contrast, if a single species is able to dominate an area to the exclusion of others, insect abundance may increase [27]. In terms of bell miners, colonies are not simply eating lerp and are likely to influence insect abundance in a range of groups beyond psyllids as they eat a lot of insects. Evidence suggests that bell miners feed their chicks a variety of insects and they breed for most of the year [42] [43] [60]. Therefore, they require habitat that contains a variety of insects to maintain successful breeding, which could relate to their despotic behaviour against other insectivorous avian species.

Assuming that the abundance of insects would increase in the absence of avian predators, we had hypothesised that the presence of insect feeding guilds in response to a change in avian predators might be reduced. If this was true, estimates of abundance based on fogging one tree in each area would potentially be underestimated. If our sampling procedure was biased towards undervaluing frequency or feeding guilds in the presence and absence of avian predators, then this could account for not observing a statistically significant level of arthropod abundance. However, we found generally that the number of families observed in each area was in fact an appropriate representation of all families that could be detected, as expected if sampling was sufficient. Therefore, our sampling protocol could not have been influenced towards underestimating the effect of avian predators because of a small sample size. Rather, the smaller number of insects captured in cones probably resulted from seasonal influences or wind blow due to the height of the cones.

Our work suggests that bell miners are not only defending psyllids, as previously suggested as being their primary food source, but also the entire insect population that is fed to their young throughout the year [12] [43] [69] [70]. Our findings are consistent with the suggestion that bell miners are opportunistic and utilise areas that 
contain high levels of lerp but also other insect species that supplement their diet [42] [43]. The effect of bell miner presence has also been shown to not necessarily be the causative agent of Glycaspis (psyllid/lerp) irruptions as the production of epicormic growth cannot be directly influenced by this species [71]. However, the presence of bell miners can reduce avian diversity and directly affect food availability for other avian species [11]. Furthermore, the increase in insect abundance in areas where bell miners are present may indicate that a variety of herbivorous insects are responsible for dieback, not only psyllids as previously suggested e.g. [45] [70].

\section{Conclusion}

A lack of a significant effect of avian predators on insect abundance and feeding guild presence that we observed represents one part of the range of effects that have been reported so far for this species. Though some studies show large effects e.g. [14] [22] [63], others show weaker effects, a small change in family diversity focusing on only psyllids or effects absent for insect consumption changes [60] [64] [65]. To date, the three studies that have examined the insect canopy assemblage in areas where bell miner colonies are present have found that insect abundance is higher where these birds are present, psyllids can be high or non existent and that feeding guilds are not affected by bell miner presence [60] [64] [65]. Further studies are essential to test whether there is an effect of seasons, climate and tree host species. The important role of avian predators in regulating insect community dynamics is emphasised in the current literature with correlated indirect effects on the host plant, such as dieback [26] [68] [72] [73]. However, a possible bias may be reflected here for publishing significant results, as suggested by Low and Connor [74]. Under some conditions, despotic birds may not change the insect canopy community. Further studies should examine the effects of a despotic bird on the insect canopy community in a variety of conditions and throughout their range.

\section{Acknowledgements}

We would like to thank all of the volunteers and rangers from National Parks and Wildlife that helped with fieldwork and choosing sites for data collection. We would also like to thank Associate Professor Graham Hall for his encouragement and advice while conducting this research.

\section{References}

[1] Clark, J.A. and Covey, K.R. (2012) Tree Species Richness and the Logging of Natural Forests: A Meta-Analysis. Forest Ecology and Management, 276, 146-153. http://dx.doi.org/10.1016/j.foreco.2012.04.001

[2] Crone, E., Menges, E., Elis, M., Bell, T., Bierzychudek, P., et al. (2011) How Do Plant Ecologists Use Matrix Population Models? Ecology Letters, 14, 1-8. http://dx.doi.org/10.1111/j.1461-0248.2010.01540.x

[3] Dangremond, E., Pardini, E. and Knight, T. (2010) Apparent Competition with an Invasive Plant Hastens the Extinction of an Endangered Lupine. Ecology, 91, 2261-2271. http://dx.doi.org/10.1890/09-0418.1

[4] Marvier, M., Kareiva, P. and Neubert, M.G. (2004) Habitat Destruction, Fragmentation, and Disturbance Promote Invasion by Habitat Generalists in a Multispecies Metapopulation. Risk Analysis, 24, 869-878. http://dx.doi.org/10.1111/j.0272-4332.2004.00485.x

[5] Marshall, M.R., Dececco, J.A., Williams, A.B., Gale, G.A. and Cooper, R.J. (2003) Use of Regenerating Clearcuts by Late-Sucessional Bird Species and Their Young during the Post-Fledging Period. Forest Ecology and Management, 183, 127-135. http://dx.doi.org/10.1016/S0378-1127(03)00101-4

[6] Begon, M., Townsend, C.R. and Harper, J.L. (2005) Ecology: From Individuals to Ecosystems. Wiley-Blackwell, Hoboken.

[7] Schowalter, T.D. (2012) Insect Responses to Major Landscape-Level Disturbance. Annual Review of Entomology, 57, 1-20. http://dx.doi.org/10.1146/annurev-ento-120710-100610

[8] Duguay, J.P., Wood, P.B. and Miller, G.W. (2000) Effects of Timber Harvests on Invertebrate Biomass and Avian Nest Success. Wildlife Society Bulletin, 28, 1123-1131.

[9] Champlin, T.B., Kilgo, J.C. and Moorman, C.E. (2009) Food Abundance Does Not Determine Bird Use of EarlySuccessional Habitat. Ecology, 90, 1586-1594. http://dx.doi.org/10.1890/08-1190.1

[10] Moorman, C.E., Bowen, L.T., Kilgo, J.C., Hanula, J.L., Horn, S., et al. (2012) Arthropod Abundance and Seasonal Bird Use of Bottomland Forest Harvest Gaps. The Wilson Journal of Ornithology, 124, 31-39.

http://dx.doi.org/10.1676/11-020.1 
[11] Leseberg, N.P., Lambert, K.T.A. and McDonald, P.G. (In Press) Fine-Scale Impacts on Avian Biodiversity Due to a Despotic Species, the Bell Miner (Manorina melanophrys). Austral Ecology, Early View.

[12] Haythorpe, K.M. and McDonald, P.G. (2010) Non-Lethal Foraging by Bell Miners on a Herbivorous Insect: Potential Implications for Forest Health. Austral Ecology, 35, 444-450. http://dx.doi.org/10.1111/j.1442-9993.2009.02099.x

[13] Higgins, P.J., Peter, J.M. and Steele, W.K., Eds. (2001) Manorina melanophrys Bell Miner. Oxford, Melbourne.

[14] Loyn, R.H., Runnalls, R.G., Forward, G.Y. and Tyers, J. (1983) Territorial Bell Miners and Other Birds Affecting Populations of Insect Prey. Science, 221, 1411-1413. http://dx.doi.org/10.1126/science.221.4618.1411

[15] Benton, T.G., Bryant, D.M., Cole, L. and Crick, H.Q.P. (2002) Linking Agricultural Practice to Insect and Bird Populations: A Historical Study over Three Decades. Journal of Applied Ecology, 39, 673-687. http://dx.doi.org/10.1046/j.1365-2664.2002.00745.x

[16] Girard, J., Baril, A., Mineau, P. and Fahrig, L. (2012) Foraging Habitat and Diet of Song Sparrows (Melospiza melodia) Nesting in Farmland: A Stable Isotope Approach. Canadian Journal of Zoology, 90, 1339-1350. http://dx.doi.org/10.1139/z2012-103

[17] Dennis, P., Skartveit, J., McCracken, D.I., Pakeman, R.J., Beaton, K., Kunaver, A. and Evans, D.M. (2008) The Effects of Livestock Grazing on Foliar Arthropods Associated with Bird Diet in Upland Grasslands of Scotland. Journal of Applied Ecology, 45, 279-287. http://dx.doi.org/10.1111/j.1365-2664.2007.01378.x

[18] Gunnarsson, B., Heyman, E. and Vowles, T. (2009) Bird Predation Effects on Bush Canopy Arthropods in Suburban Forests. Forest Ecology and Management, 257, 619-627. http://dx.doi.org/10.1016/j.foreco.2008.09.055

[19] Gunnarsson, B. (2007) Bird Predation on Spiders: Ecological Mechanisms and Evolutionary Consequences. Journal of Arachnology, 35, 509-529. http://dx.doi.org/10.1636/RT07-64.1

[20] Mooney, K.A. (2007) Tritrophic Effects of Birds and Ants on a Canopy Food Web, Tree Growth, and Phytochemistry. Ecology, 88, 2005-2014. http://dx.doi.org/10.1890/06-1095.1

[21] Recher, H.F. and Majer, J.D. (2006) Effects of Bird Predation on Canopy Arthropods in Wandoo Eucalyptus wandoo Woodland. Austral Ecology, 31, 349-360. http://dx.doi.org/10.1111/j.1442-9993.2006.01555.x

[22] Clarke, M.F. and Schedvin, N. (1999) Removal of Bell Miners Manorina melanophrys from Eucalyptus radiata Forest and Its Effect on Avian Diversity, Psyllids and Tree Health. Biological Conservation, 88, 111-120. http://dx.doi.org/10.1016/S0006-3207(98)00083-4

[23] Heyman, E. and Gunnarsson, B. (2011) Management Effect on Bird and Arthropod Interaction in Suburban Woodlands. BMC Ecology, 11, 8. http://dx.doi.org/10.1186/1472-6785-11-8

[24] Maas, B., Clough, Y. and Tscharntke, T. (2013) Bats and Birds Increase Crop Yield in Tropical Agroforestry Landscapes. Ecology Letters, 16, 1480-1487. http://dx.doi.org/10.1111/ele.12194

[25] Bereczki, K., Odor, P., Csoka, G., Mag, Z. and Baldi, A. (2014) Effects of Forest Heterogeneity on the Efficiency of Caterpillar Control Service Provided by Birds in Temperate Oak Forests. Forest Ecology and Management, 327, 96105. http://dx.doi.org/10.1016/j.foreco.2014.05.001

[26] Howes, A., Mac Nally, R., Loyn, R., Kath, J., Bowen, M., McAlpine, C. and Maron, M. (2014) Foraging Guild Perturbations and Ecological Homogenization Driven by a Despotic Native Bird Species. Ibis, 156, 341-354. http://dx.doi.org/10.1111/ibi.12136

[27] Bregman, T.P., Sekercioglu, C.H. and Tobias, J.A. (2014) Global Patterns and Predictors of Bird Species Responses to Forest Fragmentation: Implications for Ecosystem Function and Conservation. Biological Conservation, 169, 372-383. http://dx.doi.org/10.1016/j.biocon.2013.11.024

[28] Grey, M.J., Clarke, M.F. and Loyn, R.H. (1997) Initial Changes in the Avian Communities of Remnant Eucalypt Woodlands Following a Reduction in the Abundance of Noisy Miners, Manorina melanocephala. Wildlife Research, 24, 631-648. http://dx.doi.org/10.1071/WR96080

[29] Wilson, E.O. (1975) Sociobiology: The New Synthesis. Harvard University Press, Cambridge.

[30] Eason, P.K., Cobbs, G.A. and Trinca, K.G. (1999) The Use of Landmarks to Define Territorial Boundaries. Animal Behaviour, 58, 85-91. http://dx.doi.org/10.1006/anbe.1999.1133

[31] Maron, M. (2009) Nesting, Foraging and Aggression of Noisy Miners Relative to Road Edges in an Extensive Queensland Forest. Emu, 109, 75-81. http://dx.doi.org/10.1071/MU08064

[32] Stamps, J.A. (1990) The Effect of Contender Pressure on Territory Size and Overlap in Seasonally Territorial Species. American Naturalist, 135, 614-632. http://dx.doi.org/10.1086/285065

[33] Lambert, K.T.A. (2010) Comparing the Behavioural Ecology of the Cooperatively Breeding Grey-Crowned Babbler Pomatostomus temporalis temporalis in Natural and Altered Habitats. University of New England, Armidale.

[34] Betts, M.G., Hadley, A.S. and Doran, P.J. (2005) Avian Mobbing Response Is Restricted by Territory Boundaries: Experimental Evidence from Two Species of Forest Warblers. Ethology, 111, 821-835. 
http://dx.doi.org/10.1111/j.1439-0310.2005.01109.x

[35] McDonald, P.G., Olsen, P.D. and Baker-Gabb, D.J. (2003) Territory Fidelity, Reproductive Success and Prey Choice in the Brown Falcon Falco berigora: A Flexible Bet-Hedger? Australian Journal of Zoology, 51, 399-414. http://dx.doi.org/10.1071/ZO02059

[36] Ford, H.A. (1979) Interspecific Competition in Australian Honeyeaters-Depletion of Common Resources. Australian Journal of Ecology, 4, 145-164. http://dx.doi.org/10.1111/j.1442-9993.1979.tb01205.x

[37] Feinsinger, P. and Colwell, R.K. (1978) Community Organisation among Neotropical Nectar-Feeding Birds. Integrative and Comparitve Biology, 4, 779-795.

[38] Piper, S.D. and Catterall, C.P. (2003) A Particular Case and a General Pattern: Hyperaggressive Behaviour by One Species May Mediate Avifaunal Decreases in Fragmented Australian Forests. Oikos, 101, 602-614. http://dx.doi.org/10.1034/j.1600-0706.2003.12292.x

[39] Clark, M.F. and Schedvin, N. (1999) Removal of Bell Miners Manorina melanophrys from Eucalyptus radiata Forest and Its Effect on Avian Diversity, Psyllids and Tree Health. Biological Conservation, 88, 111-120.

[40] Kemmerer, E.P., Shields, J.M. and Tidemann, C.R. (2008) High Densities of Bell Miners Manorina melanophrys Associated with Reduced Diversity of Other Birds in Wet Eucalypt Forest: Potential for Adaptive Management. Forest Ecology and Management, 255, 2094-2102. http://dx.doi.org/10.1016/j.foreco.2007.12.035

[41] Landsberg, J. (2006) Dieback of Rural Eucalypts: Tree Phenology and Damage Caused by Leaf-Feeding Insects. Australian Journal of Ecology, 13, 251-267. http://dx.doi.org/10.1111/j.1442-9993.1988.tb00973.x

[42] teMarvelde, L., McDonald, P.G., Kazem, A.J.N. and Wright, J. (2009) Do Helpers Really Help? Provisioning Biomass and Prey Type Effects on Nestling Growth in the Cooperative Bell Miner. Animal Behaviour, 77, 727-735. http://dx.doi.org/10.1016/j.anbehav.2008.12.008

[43] Poiani, A. (1993) Bell Miners: What Kind of Farmers Are They? Emu, 93, 188-194. http://dx.doi.org/10.1071/MU9930188

[44] Loyn, R.H. (1987) The Bird that Farms the Dell. Natural History, 6, 54-60.

[45] Wardell-Johnson, G., Stone, C., Recher, H. and Lynch, A.J.J. (2005) A Review of Eucalypt Dieback Associated with Bell Miner Habitat in South-Eastern Australia. Australian Forestry, 68, 231-236.

[46] Petchey, O.L. and Gaston, K.J. (2006) Functional Diversity: Back to Basics and Looking Forward. Ecology Letters, 9, 741-758. http://dx.doi.org/10.1111/j.1461-0248.2006.00924.x

[47] Zborowski, P. and Storey, R., Eds. (2010) A Field Guide to Insects in Australia. 3rd Edition, New Holland Publishers (Australia) Pty Ltd., Sydney.

[48] Hooper, D.U., Solan, M., Symstad, A., Diaz, S., Gessner, M.O., et al. (2002) Species Diversity, Functional Diversity, and Ecosystem Functioning. In: Loreau, M., Naeem, S. and Inchausti, P., Eds., Biodiversity and Ecosystem Functioning: Synthesis and Perspectives, Oxford University Press, Oxford, 185-281.

[49] Andrew, N.R. and Hughes, L. (2005) Arthropod Community Structure along a Latitudinal Gradient: Implications for Future Impacts of Climate Change. Austral Ecology, 30, 281-297. http://dx.doi.org/10.1111/j.1442-9993.2005.01464.x

[50] Poiani, A. (1992) Feeding of the Female Breeder by Male Helpers in the Bell Miner Manorina melanophrys. Emu, 92, 233-237. http://dx.doi.org/10.1071/MU9920233

[51] Poiani, A. (1997) Prey Delivered to Bell Miner Nestlings: Is There Division of Labour among Nest Attendants? Emu, 97, 87-90. http://dx.doi.org/10.1071/MU97010

[52] Bureau of Meteorology (2014) Summary Statistics Glen Innes Post Office. Commonwealth of Australia, Melbourne.

[53] Bureau of Meteorology (2014) Summary Statistics Belligen Post Office. Commonwealth of Australia, Melbourne.

[54] Adis, J., Basset, Y., Floren, A., Hammond, P.M. and Linsenmair, K.E. (1998) Canopy Fogging of an Overstorey Tree-Recommendations for Standardization. Ecotropica, 4, 93-97.

[55] Andrew, N.R. and Hughes, L. (2004) Species Diversity and Structure of Phytophagous Beetle Assemblages along a Latitudinal Gradient: Predicting the Potential Impacts of Climate Change. Ecological Entomology, 29, 527-542. http://dx.doi.org/10.1111/j.0307-6946.2004.00639.x

[56] Andrew, N.R. and Hughes, L. (2005) Diversity and Assemblage Structure of Phytophagus Hemiptera along a Latitudinal Gradient: Predicting the Potential Impacts of Climate Change. Global Ecology and Biogeography, 14, 249-262. http://dx.doi.org/10.1111/j.1466-822x.2005.00149.x

[57] Samways, M.J., McGeoch, M.A. and New, T.R. (2010) Insect Conservation: A Handbook of Approaches and Methods. Oxford University Press Inc., New York.

[58] Quin, G.P. and Keough, M.J. (2002) Experimental Design and Data Analysis for Biologists. Cambridge University Press, Cambridge. http://dx.doi.org/10.1017/CBO9780511806384 
[59] Gotelli, N.J. and Colwell, R.K. (2011) Estimating Species Richness. In: Biological Diversity: Frontiers in Measurement and Assessment, Oxford University Press, United Kingdom, 39-54.

[60] Poiani, A. (1993) Reproductive Biology of the Bell Miner (Manorina melanophrys, Meliphagidae) at Healesville, South-Eastern Victoria. Wildlife Research, 20, 579-597. http://dx.doi.org/10.1071/WR9930579

[61] Dare, A.J., McDonald, P.G. and Clarke, M.F. (2008) The Ecological Context and Consequences of Colonisation of a Site by Bell Miners (Manorina melanophrys). Wildlife Research, 34, 616-623. http://dx.doi.org/10.1071/WR07015

[62] Whelan, C.J. (2001) Foliage Structure Influences Foraging of Insectivorous Forest Birds: An Experimental Study. Ecology, 82, 219-231. http://dx.doi.org/10.1890/0012-9658(2001)082[0219:FSIFOI]2.0.CO;2

[63] Stone, C. (1996) The Role of Psyllids (Hemiptera: Psyllidae) and Bell Miners (Manorina melanophrys) in Canopy Dieback of Sydney Blue Gum (Eucalyptus saligna Sm.). Austral Ecology, 21, 450-458. http://dx.doi.org/10.1111/j.1442-9993.1996.tb00631.x

[64] Poiani, A. (1993) Effects of Clutch Size Manipulations on Reproductive Behaviour and Nesting Success in the Cooperatively Breeding Bell Miner (Manorina melanophrys). Evolutionary Ecology, 7, 329-356. http://dx.doi.org/10.1007/BF01237866

[65] Dare, A. (2010) Processes Influencing Habitat Selection in Bell Miners Manorina melanophrys. La Trobe University, Bundoora, 1-142 p.

[66] Campbell, K.G. and Moore, K.M. (1957) An Investigation of the Food of the Bell Bird Manorina melanophrys Latham. Proceedings of the Royal Society of NSW 1955-56, 72-73.

[67] Tyers, J.A. (1981) Energetics of the Bell Miner (Manorina melanophrys) and Its Association with Psyllids (Homoptera) and Eucalypt Crown Dieback [Honours]. Monash University, Melbourne.

[68] Wenny, D.G., Devault, T.L., Johnson, M.D., Kelly, D., Sekercioglu, C.H., et al. (2011) The Need to Quantify Ecosystem Services Provided by Birds. The Auk, 128, 1-14. http://dx.doi.org/10.1525/auk.2011.10248

[69] Wardell-Johnson, G. and Lynch, A.J.J. (2005) Landscape Processes and Eucalypt Dieback Associated with Bell Miner Habitat in South-Eastern Australia. Australian Forestry, 68, 242-250. http://dx.doi.org/10.1080/00049158.2005.10674972

[70] Stone, C. (2005) Bell-Miner-Associated Dieback at the Tree Crown Scale: A Multi-Trophic Process. Australian Forestry, 68, 237-241. http://dx.doi.org/10.1080/00049158.2005.10674971

[71] Steinbauer, M., Sinai, K., Anderson, A., Taylor, G.S. and Horton, B.M. (2014) Trophic Cascades in Bell Miner-Associated Dieback Forests: Quantifying Relationships between Leaf Quality, Psyllids and Psyllaephagus Parasitoids. Austral Ecology, Early View. http://dx.doi.org/10.1111/aec.12170

[72] Ford, H.A. and Bell, H. (1981) Density of Birds in Eucalypt Woodland Affected to Varying Degrees by Dieback. Emu, 81, 202-208. http://dx.doi.org/10.1071/MU9810202

[73] Ford, H. (2011) The Causes of Decline of Birds of Eucalypt Woodlands: Advances in Our Knowledge over the Last 10 Years. Emu, 111, 1-9. http://dx.doi.org/10.1071/MU09115

[74] Low, C. and Connor, E.F. (2003) Birds Have No Impact on Folivorous Insect Guilds on a Montane Willow. Oikos, 103, 579-589. http://dx.doi.org/10.1034/j.1600-0706.2003.12628.x 
Scientific Research Publishing (SCIRP) is one of the largest Open Access journal publishers. It is currently publishing more than 200 open access, online, peer-reviewed journals covering a wide range of academic disciplines. SCIRP serves the worldwide academic communities and contributes to the progress and application of science with its publication.

Other selected journals from SCIRP are listed as below. Submit your manuscript to us via either submit@scirp.org or Online Submission Portal.
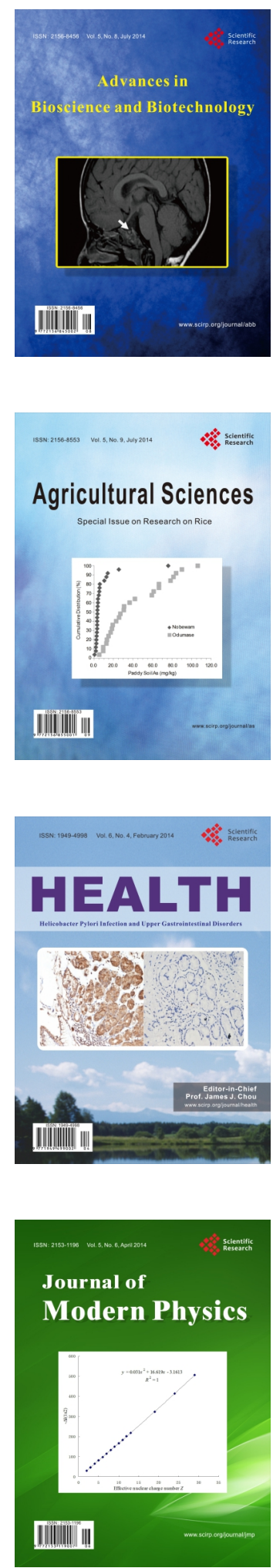
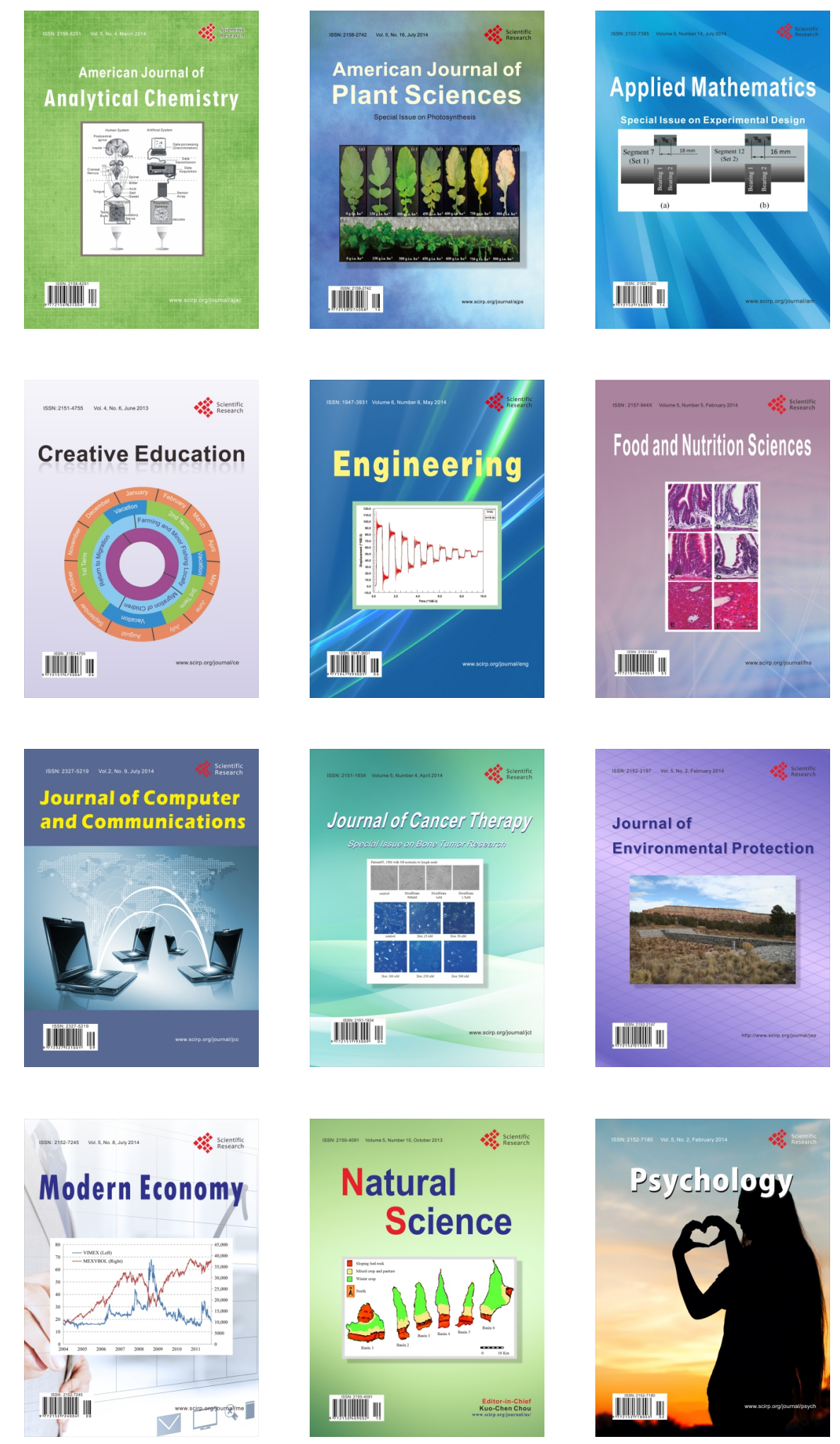